\title{
Effect of Simulated Plow-sole on Water Uptake and Yield of Dryland Wheat ${ }^{1}$
}

\author{
S. S. Prihar, Piara Singh, and P. R. Gajri ${ }^{2}$
}

\section{ABSTRACT}

Yield of dryland crops grown on stored water is determined by water use from the profile which, in turn, is related to the extent of root proliferation in different layers. Plow-soles of high strength may retard root growth and adversely affect crop production. We determined the effect of initial profile water storage and soil compaction below the seed on the growth and the yield of dryland wheat, (Triticum aestivum $L_{\text {.) }}$ in field experiments during 1970-71 and 1971-72. Compaction reduced water use from deeper layers and decreased grain yield during both years. Evidently, it retarded root growth through increased soil strength. Compared with lower initial water storage, higher initial water storage in the profile resulted in more vigorous plants, deeper rooting, greater water use from lower soil layers and higher yields.

The results suggest that for greatest yields, compact layers below the seed must be loosened by tillage to permit deeper rooting. Also, in the absence of early season rain, a small supplementary irrigation to the young crop may stimulate deeper rooting and increase water use from lower layers.

Additional index words: Soil compaction, Rooting pattern, Moisture use, Seeding-time soil water, Dryland wheat production.

W HERE precipitation during the growing season is low and supplemental irrigation is not available, crop yields are mainly determined by the

\footnotetext{
${ }^{1}$ Contribution from Department of Soils, Punjab Agricultural University, Ludhiana, India. Received Mar. 21, 1974.

" Professor of Soil Physics, PAU, Ludhiana, Research Associate, ICRISAT Hyderabad, and Soil Science (Extension) Specialist, PAU, Ludhiana, respectively.
}

utilization of water stored in the soil. The amount of stored water that becomes available to the crop is directly proportional to depth of rooting and extent of root proliferation in different soil layers. Factors that reduce root growth would reduce yields in dryland crops by reducing soil-water utilization. Increased soil strength is known to retard root growth (Gill and Miller, 1956; Taylor, Roberson, and Parker, 1967) and to reduce root elongation rates. When the soil strength exceeds a certain threshold value (Zimmerman and Kardos, 1961; Barley, Farrell, and Greacen, 1965; Barley and Greacen, 1967; Taylor and Bruce, 1968), root penetration is retarded. Soil strength is a function of bulk density and soil moisture tension (Taylor and Gardner, 1963). At high soil moisture tension, which usually occurs in the surface layers of unirrigated soils, the soil strength may be considerably increased by a small increase in bulk density. The root growth thus may, be hampered even by mild plow-soles under unirrigated conditions. Much of the research on soil compaction under dryland conditions in the past has been conducted with crop plants which have tap roots. Consequently, there is a great need for more information on crops, such as wheat, (Triticum aestivum L.) which have fibrous root systems.

This report describes the results of a 2-year study on the effect of simulated plow-soles and initial profile water storage on the water use and yield of dryland wheat. 
Table 1. Physical characteristics of the soil from experimental site.

\begin{tabular}{|c|c|c|c|c|c|c|c|}
\hline \multirow{3}{*}{$\begin{array}{l}\text { Soil } \\
\text { depth } \\
\mathrm{cm}\end{array}$} & \multirow[b]{2}{*}{ Sand } & \multirow[b]{2}{*}{ Silt } & \multirow[b]{2}{*}{ Clay } & \multirow{2}{*}{$\begin{array}{l}\text { Textural } \\
\text { class }\end{array}$} & \multirow{3}{*}{$\begin{array}{c}\text { Bulk } \\
\text { density } \\
\mathrm{g} \mathrm{cm-3}\end{array}$} & \multicolumn{2}{|c|}{ Molsture retention } \\
\hline & & & & & & $1 / 3 \mathrm{bar}$ & $15 \mathrm{bar}$ \\
\hline & & $\%$ & & & & \multicolumn{2}{|c|}{$\mathrm{cm}^{3} \mathrm{~cm}^{-3}$} \\
\hline $0-15$ & 79 & 7 & 14 & Sandy loam & 1,46 & 0.140 & 0.053 \\
\hline $15-55$ & 62 & 16 & 22 & Loam & 1,31 & 0,201 & 0.091 \\
\hline $55-105$ & 51 & 15 & 24 & Clay loam & 1. 29 & 0.210 & 0.094 \\
\hline $105-145$ & 65 & 14 & 21 & Loam & 1.27 & 0.183 & 0.078 \\
\hline $145-180$ & 81 & 7 & 12 & Sandy loam & 1. 32 & 0,109 & 0.045 \\
\hline
\end{tabular}

\section{EXPERIMENTAL PROCEDURE}

Field experiments were conducted on sandy loam soil during 1970-71 and 1971-72. Physical characteristics of the soil profile are given in Table 1. These soils have been developed from alluvium of pleistocene to recent times under ustic moisture regime. Loamy sand to sandy loam at the surface and loam in the subsurface, they belong to the family : fine loamy, hyperthermic, mixed, calcareous, typic ustochrept (Sehgal and Cys, 1970).

Treatments included (i) no compaction $\left(\mathrm{C}_{0}\right)$ and (ii) simulated plow-sole created by compaction $\left(\mathrm{C}_{1}\right)$ at low $\left(\mathrm{W}_{1}\right)$ and high $\left(W_{2}\right)$ initial profile water storage obtained by varying the amount of presowing application. Soil water content in different layers under low and high water storage is shown in Table 2. To create plow-sole, the entire surface was compacted at soil water contents shown in Table 2 with the wheels of a $1,700 \mathrm{~kg}$ tractor which exerted a pressure of $0.65 \mathrm{~kg} \mathrm{~cm}^{-3}$. Fresh compaction was done both years. Immediately after compaction wheat was sown in furrows made by a single-row, bullock-drawn indigenous wooden plow having a metallic tip. This operation loosened the approx. upper $8 \mathrm{~cm}$ layer and left a slightly dense layer below. After the soil was settled by rain during the growing season soil clods were obtained from 0 to $7.5,7.5$ to 15 and 15 to $22.5 \mathrm{~cm}$ layers and their bulk density was determined by the saturation method of Prihar and Hundal (1971). Distribution of bulk density in different treatments is shown in Table 3.

Semidwarf wheat, 'Kalyan 227,' was planted in $30 \mathrm{~cm}$ wide rows in $10 \times 3 \mathrm{~m}$ plots in five replicates on Nov. 30,1970 and in $22.5-\mathrm{cm}$ rows in $10 \times 3 \mathrm{~m}$ plots in six replicates on Nov. 24 , 1971. Galcium ammonium nitrate and superphosphate to supply $45 \mathrm{~kg} \mathrm{~N}+45 \mathrm{~kg} \mathrm{P}_{2} \mathrm{O}_{5}$ and $50 \mathrm{~kg} \mathrm{~N}+30 \mathrm{~kg} \mathrm{P}_{2} \mathrm{O}_{5} / \mathrm{ha}$ were drilled below the seed during $1970-7 \mathrm{I}$ and $1971-72$, respectively. Crop was harvested in the first week of May during both years. In addition to measuring grain and straw, plant height, grains per spike, and 1,000 grain weight were recorded.

Cumulative rainfall and evaporation from U.S. Weather Bureau Class A Pan for the two growing seasons are shown in Fig. 1. Soil moisture content was determined periodically in 0 to 15,15 to 30,30 to 60,60 to 90,90 to 120,120 to 150 and 150 to $180 \mathrm{~cm}$ layers in three replications except at harvest, when the sampling could be done in two replications only.

\section{RESULTS}

\section{Growth and Yield}

Effect of Initial Water Storage. Table 4 shows that during $1970-71$ season grain yield was significantly higher $(P=0.05)$ by $265 \mathrm{~kg}$ (L.S.D. $=138 \mathrm{~kg}$ ) in the high water storage $\left(W_{2}\right)$ than in the low water storage treatment $\left(W_{1}\right)$ groups. In the following year, however, a difference of $200 \mathrm{~kg} / \mathrm{ha}$ in grain yield between $W_{2}$ and $W_{1}$ was not significant $(\mathbf{P}=0.05)$. Average straw yield with $W_{2}$ was $41 \%$ higher than that with $W_{1}$ in 1970-71. Plants in high water storage plots were significantly taller by $4.3 \mathrm{~cm}$ than those in lower moisture storage in 1970-71. Number of grains per ear was also significantly greater in $W_{2}$ than in $W_{1}$ in 1970-71.

In 1971-72, the difference in plant height, straw yield, number of grains per spike, and 1,000 grain

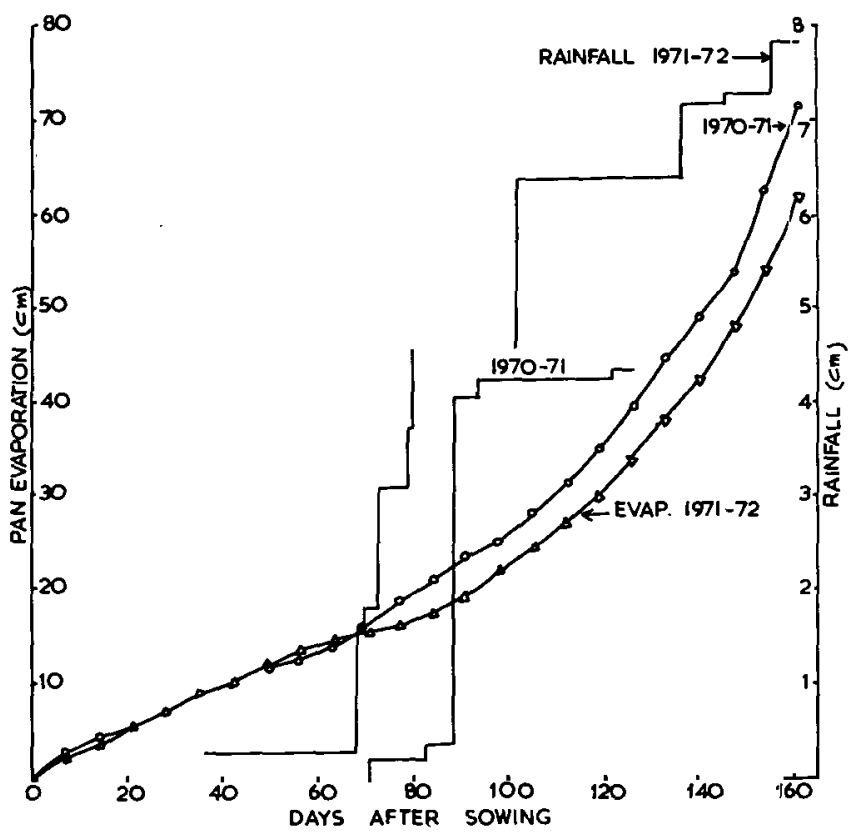

Fig. 1. Cumulative pan evaporation and rainfall during growth seasons.

weight, due to initial soil water storage were not statistically significant. Initial profile water storage $X$ compaction interaction in respect of grain yield and plant height during both years was not significant.

Effect of Compaction. In both years, compaction significantly reduced grain yield, straw yield, and plant height. Decrease in grain yield with compaction averaged $334 \mathrm{~kg} / \mathrm{ha}$ or $29 \%$ during $1970-71$ and 218 $\mathrm{kg} / \mathrm{ha}$ or $7 \%$ during 1971-72. Averaged over other factors, the mean straw yield with compaction was $19 \%$ and $15 \%$ less than no compaction during $19 \% 0-71$ and 1971.72 , respectively. The difference in plant height was greater in the first than in the second year. Mean decrease in height with compaction was $5.1 \mathrm{~cm}$ in the first and $2.4 \mathrm{~cm}$ in the second year. The differences in number of grains per spike and 1,000-grain weight due to compaction were not significant.

\section{WATER USE}

Effect of Initial Water Storage. Mean water use by the crop was 4.7 and $3.5 \mathrm{~cm}$ greater in $W_{2}$ than in $W_{1}$ during $1970-71$ and 1971-72, respectively. During 1970 71 , water use with $W_{2}$ as compared to $W_{1}$ was 5.4 and $4.0 \mathrm{~cm}$ higher in no compaction $\left(\mathrm{C}_{0}\right)$ and compaction $\left(\mathrm{C}_{1}\right)$, respectively. Similarly, during 1971-72, the water use in $W_{2}$ compared with $W_{1}$ was 3.6 and $3.3 \mathrm{~cm}$ more in $\mathrm{C}_{0}$ and $\mathrm{C}_{1}$, respectively. Also cumulative water use in $W_{2}$ remained higher than that in $W_{1}$ throughout the growing season of the crop in both the years (Fig. 2 and 3). Note that higher initial moisture storage resulted in greater moisture depletion from lower layers of the soil (Fig. 4). Furthermore, the crop depleted profile moisture to below 15 bar tension (Fig. 4 and 5). 
Table 2. Sowing time water content distribution in the different soil layers under low and high water storage during $1970-71$ and 1971.72.

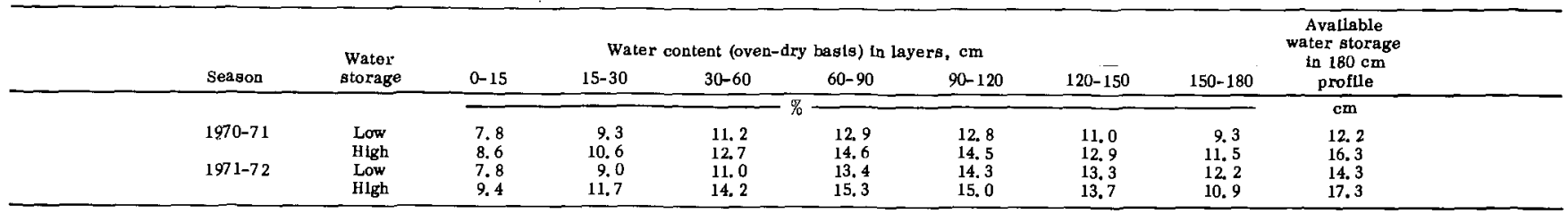

Table 3. Vertical distribution of bulk density in different treatments.

\begin{tabular}{|c|c|c|c|c|c|c|}
\hline \multirow{2}{*}{$\begin{array}{l}\text { Treat- } \\
\text { ments }\end{array}$} & \multicolumn{3}{|c|}{ 1970-71 season, cm } & \multicolumn{3}{|c|}{$1971-72$ season, cm } \\
\hline & $0-7.5$ & $7.5-15.0$ & $15.0-22.5$ & $0-7.5$ & $7.5-15.0$ & $15.0-22.5$ \\
\hline & & 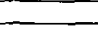 & $\mathrm{g} \mathrm{cr}$ & & & \\
\hline $\mathrm{w}_{1} \mathrm{C}_{0}$ & $--^{\dagger}$ & - & -- & 1.52 & 1. 56 & 1,51 \\
\hline $\begin{array}{l}W_{1}^{1} c_{1} \\
w_{2} C_{0}\end{array}$ & $\overline{1.43}$ & $\overline{1.56}$ & $\begin{array}{r}--47 \\
1.47\end{array}$ & $\begin{array}{l}\text { 1. } 53 \\
\text { 1. } 57\end{array}$ & $\begin{array}{l}1.59 \\
1.61\end{array}$ & $\begin{array}{l}1.53 \\
1.51\end{array}$ \\
\hline $\mathrm{w}_{2} \mathrm{C}_{1}^{0}$ & 1.55 & 1.64 & 1.45 & 1.64 & 1.71 & 1.51 \\
\hline
\end{tabular}

Table 4. Growth and yield components on plots with different water storage and compaction during 2 years.

\begin{tabular}{|c|c|c|c|c|c|c|}
\hline \multirow[b]{2}{*}{$\begin{array}{l}\text { Water } \\
\text { storage }\end{array}$} & \multicolumn{3}{|c|}{ 1970-71 season } & \multicolumn{3}{|c|}{$1971-72$ season } \\
\hline & $\begin{array}{c}\text { No } \\
\text { compact. }\end{array}$ & Compact. & Mean & $\begin{array}{c}\text { No } \\
\text { compact. }\end{array}$ & Compact. & Mean \\
\hline \multicolumn{7}{|c|}{ Plant height at harvest, $\mathrm{cm}$} \\
\hline $\begin{array}{l}\text { Low } \\
\text { Hlgh }\end{array}$ & $\begin{array}{l}66.6 \\
71.0\end{array}$ & $\begin{array}{l}61.6 \\
65.8\end{array}$ & $\begin{array}{l}64.1 \\
68.4\end{array}$ & $\begin{array}{l}79.8 \\
82.6\end{array}$ & $\begin{array}{l}77.0 \\
81.2\end{array}$ & $\begin{array}{l}78.4 \\
81.9\end{array}$ \\
\hline & & & 66.2 & & & \\
\hline $\begin{array}{l}\text { Compact. } \\
\text { Molst. stor. }\end{array}$ & $\begin{array}{l}1.15 \\
3.45\end{array}$ & & & $\begin{array}{l}2.21 \\
\mathrm{NS}\end{array}$ & & \\
\hline \multicolumn{7}{|c|}{ Graln yleld, $\mathrm{kg} / \mathrm{ha}$} \\
\hline Low & 995 & 705 & 850 & 2949 & 2768 & 2858 \\
\hline $\begin{array}{l}\text { Hlgh } \\
\text { Mean }\end{array}$ & $\begin{array}{l}1304 \\
1149\end{array}$ & $\begin{array}{l}926 \\
815\end{array}$ & 1115 & $\begin{array}{l}3186 \\
3067\end{array}$ & $\begin{array}{l}2931 \\
2849\end{array}$ & $\begin{array}{l}3058 \\
2958\end{array}$ \\
\hline Compact. & 163 & & D. $(0.05)$ & 150 & & \\
\hline Molst. stor. & 138 & & & NS & & \\
\hline \multicolumn{7}{|c|}{ Straw yleld. kg/ha } \\
\hline Low & 1530 & 1172 & 1351 & 3453 & 3070 & 3261 \\
\hline Hlgb & 2069 & 1747 & 1908 & 4125 & 3358 & 3741 \\
\hline Mean & & 1459 & $\begin{array}{l}1629 \\
\text { D. }(0.05)\end{array}$ & 3789 & & \\
\hline $\begin{array}{l}\text { Compact. } \\
\text { Molst, stor. }\end{array}$ & $\begin{array}{r}32 \\
289\end{array}$ & & & $\begin{array}{l}342 \\
\text { NS }\end{array}$ & & \\
\hline \multicolumn{7}{|c|}{ No. of gralne per spike } \\
\hline Low & 33 & 35 & 34 & 56 & 58 & 57 \\
\hline High & 40 & 39 & 39.5 & 56 & 57 & 56.5 \\
\hline Mean & 36.5 & 37 & 36.7 & 56 & 57.5 & \\
\hline $\begin{array}{l}\text { Compact. } \\
\text { Molst. ator. }\end{array}$ & $\begin{array}{l}\text { NS } \\
5.19\end{array}$ & & & $\begin{array}{l}\text { NS } \\
\text { NS }\end{array}$ & & \\
\hline \multicolumn{7}{|c|}{1,000 grain weight, $g$} \\
\hline & 26.17 & & 26.14 & 31.25 & 31.71 & 31.48 \\
\hline High & 28. 35 & 28.15 & 28. 25 & 30.76 & 31.66 & 31.21 \\
\hline & & \multirow{2}{*}{\multicolumn{2}{|c|}{ L. S. D. $(0.05)$}} & 31.00 & 31.68 & \\
\hline $\begin{array}{l}\text { Compact. } \\
\text { Moist. stor. }\end{array}$ & $\begin{array}{l}\text { NS } \\
\text { NS }\end{array}$ & & & $\begin{array}{l}\text { NS } \\
\text { NS }\end{array}$ & & \\
\hline
\end{tabular}

Table 5. Effect of compaction and water storage on water use during 2 years.

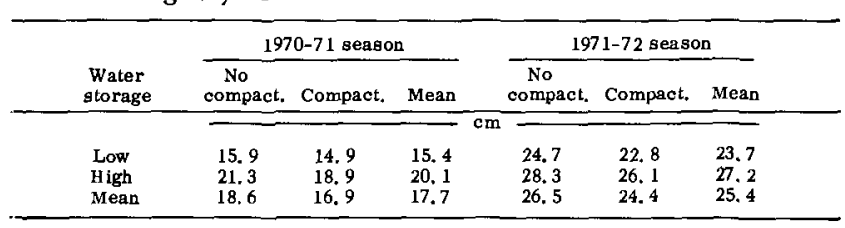

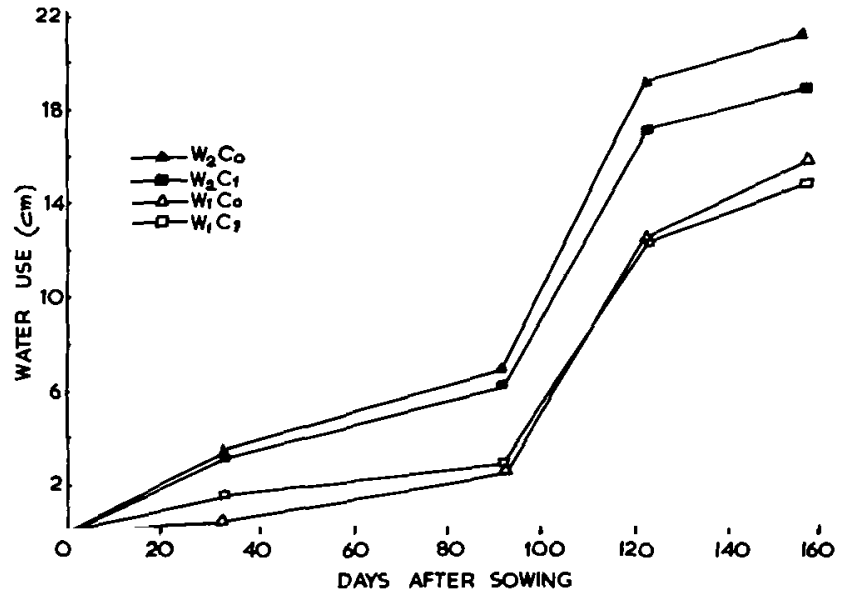

Fig. 2. Cumulative moisture use by the crop under different treatments during 1970-71. Each point is a mean of nine observations.

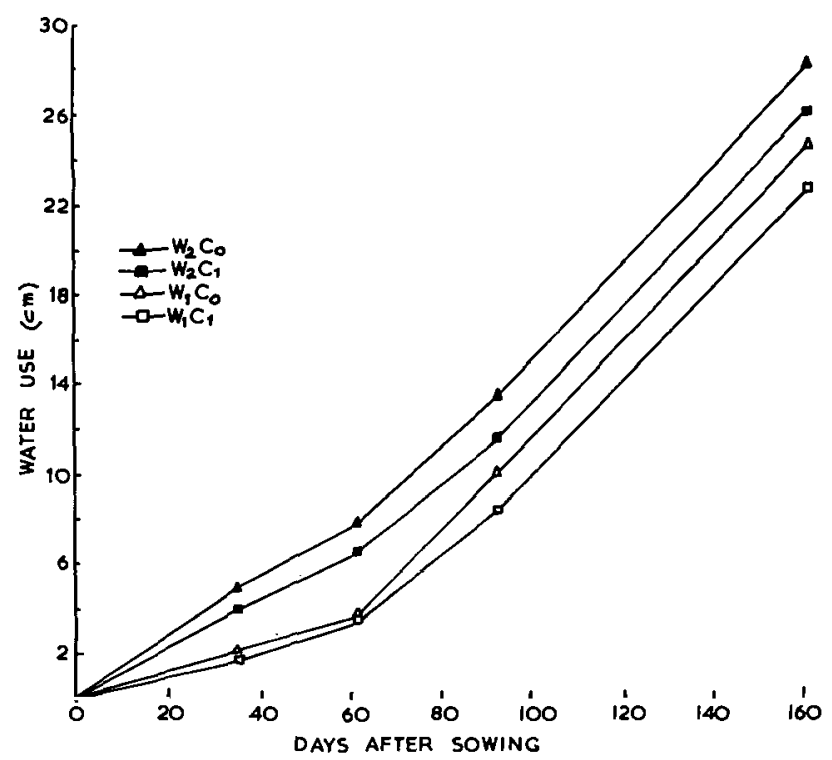

Fig. 3. Cumulative moisture use by the crop under different treatments during 1971.72. Each point is a mean of six observations. 


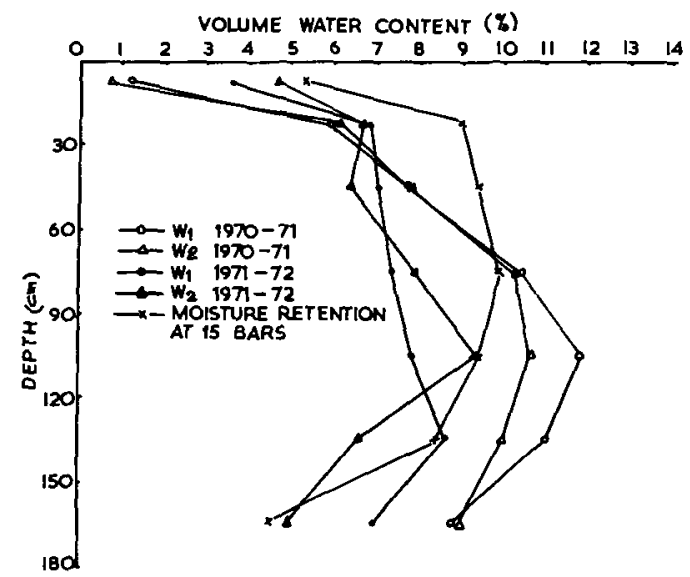

Fig. 4. Effect of initial water storage in the soil profile on moisture profile at harvest. Each point is a mean of 12 and 8 observations in the year $1970-71$ and 1971-72, respectively.

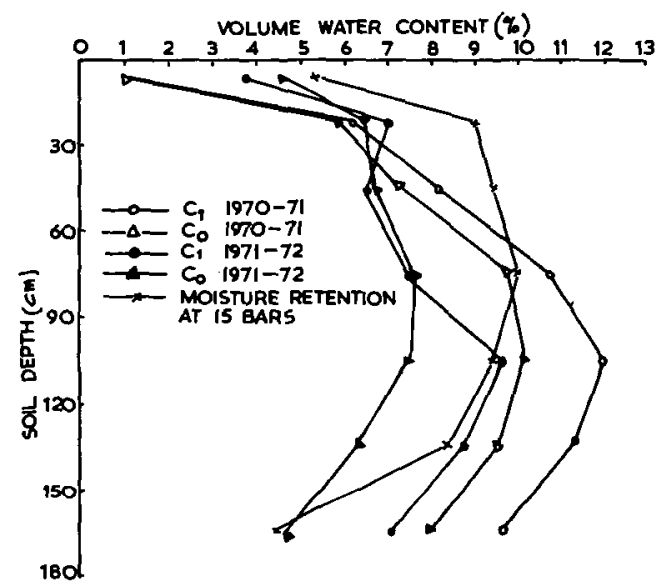

Fig. 5. Effect of compaction on water content in soil profile at harvest. Each point is a mean of 12 observations in the year 1970-71. $C_{0}$ and $C_{1}$ is mean of eight and four observations, respectively, in the year $1971-72$.

Effect of Compaction. Compaction generally reduced water use by the crop. Under $W_{1}$, the water use in $1970-71$ and $1971-72$, respectively was 1.0 and 1.9 cm lower with compaction than without compaction. Similarly, under $W_{2}$, the water use was reduced by 2.4 and $2.2 \mathrm{~cm}$ during 1970.71 and 1971-72, respectively. Average decrease in water use with $\mathrm{C}_{1}$ was $1.7 \mathrm{~cm}$ in $1970-71$ and $2.1 \mathrm{~cm}$ in 1971-72. Cumulative water use in $W_{1}$ was also higher in $C_{0}$ than in $C_{1}$ throughout the growing season in both the years (Fig. 2 and 3).

\section{DISCUSSION AND CONCLUSIONS}

A significant reduction in grain yield with compaction during both the years is accompanied by reduced water use (Table 5). During both years, the adverse effect of compaction on yield as well as water use was more pronounced under $W_{2}$ than $W_{1}$. This is apparently related to higher bulk density in the top $15 \mathrm{~cm}$ caused by compaction in $W_{2}$ compared with
$W_{1}$. It is seen from Table 3 that during 1971-72, bulk density in 7.5 to $15 \mathrm{~cm}$ layer in the compaction treatment was 1.71 and $1.59 \mathrm{~cm}^{-3}$ in $W_{2}$ and $W_{1}$, respectively. The pattern of water uptake (Fig. 5) revealed that during both the years compaction reduced water use from the layers below $75 \mathrm{~cm}$. Water uptake from the upper $75 \mathrm{~cm}$ layer was affected negligibly by compaction. In the absence of frequent wetting by irrigation or rain, the water uptake pattern is a good index. of root distribution pattern. Obviously, therefore, compaction decreased ramification of roots in the deeper layers. Reduced root growth with compaction may be attributed to increased soil strength, reduced aeration, or changes in soil-water relations and heat flux (Rosenberg, 1964). Effect of the latter two factors is usually small. In the relatively dry moisture regime obtained in these experiments, aeration is unlikely to limit root growth. Evidently, therefore, compaction retarded the root growth through increased soil strength.

Higher water use (Table 5) and uptake from lower layers in $W_{2}$ than in $W_{1}$ during both the years (Figg. 4) indicated that higher initial water content stimulated deeper root penetration. It appears that higher soil water content in $\mathrm{W}_{2}$ kept the soil strength lower (Taylor and Gardner, 1963) and permitted greater root elongation (Taylor et al., 1967) in the early stages. A more extensive root system in the young plant resulted in greater uptake of nutrients and water which, in turn, increased plant vigor.

Higher moisture use and greater extraction from layers below $30 \mathrm{~cm}$ during 1971-72 than during 197071 is apparently related to the differences in rainfall pattern during the 2 years. During 1970-71, only $3 \mathrm{~mm}$ of rain was received up to 89 days after planting. This caused drying of surface layers and retarded the crop growth. After a rainstorm of $36 \mathrm{~mm}$ on February 27 the crop resumed growth and the rate of moisture use experienced a steep rise (Fig. 2). Unlike 1970-71, rainfall during 1971-72 started earlier in the season and by 80 days of planting $46 \mathrm{~mm}$ of rain fell. Thus, the early growth of crop was not affected adversely.

February water use was manyfold greater in 1971-72 than in 1970-71. Total rainfall during 1971-72 was $78 \mathrm{~mm}$ against $43 \mathrm{~mm}$ during 1970-71. Better crop growth, resulting from better distribution of rainfall, caused deeper rooting and greater proliferation in the lower depth. These results suggest that in the absence of early season rain, a small supplementary irrigation may stimulate extraction of moisture from deeper layers of the profile during later parts of the growth period. Ritchie, Burnett, and Henderson (1972) also indicated that plants subjected to early stress do not have an opportunity to develop a root system with adequate density to extract water from lower soil depths.

\section{LITERATURE CITED}

Barley, K. P., D. A. Farrell, and E. L. Greacen. 1965. The influence of soil strength on the penetration of a loam by plant roots. Aust. J, Soil Res, 3 : 69-79.

-_- and E.L. Greacen. 1967. Mechanical resistance: as a soil factor influencing the growth of roots and under ground shoots. Adv. Agron. $19: 1.43$. 
Gill, W.R., and R.D. Miller. 1956. A method for the study of the influence of mechanical impedance and aeration on the growth of seedling roots. Soil Sci. Am. Proc. 20 : 154-157.

Prihar, S.S., and S.S. Hundal. 1971. Determination of bulk density of soil clod by saturation. Geoderma $5: 283-286$.

Ritchie, J.T., E. Burnett, and R.C. Henderson 1972. Dryland evaporative flux in sub-humid climate IUI. Soil Water in. fluence. Agron. J. 64. : 168-173.

Rosenberg, N.J. 1964. Response of plants to the physical effects of soil compaction. Adv. Agron. 16: 181-196.

Sehgal, I.L., and C. Cys. 1970. The soils of Punjab, India. III Classification and geographic distribution. Pedologie (Ghent) $20: 357-380$.
Taylor, H.M., and R.R. Bruce. 1968. Effect of soil strength on root growth and crop yield in Southern United States. Int. Congr. Soil Sci. Trans. 9th I : 803-811.

- - , and H.R. Gardner. 1963. Penetration of cotton seedling tap roots as influenced by bulk density, moisture content and strength of soil. Soil Sci. $96: 153-156$.

- - . G.M. Roberson, and J.J. Parker, Jr, 1967. Cotton seedling tap root elongation as affected by soil strength changes induced by slurring and water extraction. Soil Sci. Soc. Am. Proc. 31 : 700-703.

Zimmerman, R.P., and L.T. Kardos. 1961. Effect of bulk density on root growth. Soil Sci. $91: 280-288$. 